\title{
ASPIRASI KARIER SISWA SMA BERDASARKAN STATUS SOSIAL EKONOMI DAN GENDER
}

\author{
Nunik Widiastuti ${ }^{1}$
}

\begin{abstract}
Career Aspirations of SMA Students Based Socio-Economic Status and Gender. This research is a descriptive study about career aspirations aimed to describe the career aspirations of students by socio-economic status and gender in SMA Negeri 1 Batujajar. The method used the quantitative descriptive method. Respondents in this study are students of class X SMA Negeri 1 Batujajar that are at the stage of self-orientation. At this stage people start selecting, establishing and looking for alternatives on the planning himself and his work. Selection of the sample using purposive sampling techniques so that the respondents in this study were 234 students. In general, the career aspirations of students $10.3 \%$ were in the low category, which is the category of being as much as $63.2 \%$, and $26.5 \%$ At the high category. Based on the socioeconomic status of education last seen parents are in the moderate category. Based on parent income in middle category. Meanwhile, based on the gender ratio of the career aspirations of learners battery and men do not have a difference, with a probability value of 0.53 .
\end{abstract}

Keywords: Career Aspiration, Gender, Socio-Economic Status.

\section{INDONESIAN JOURNAL OF EDUCATIONAL COUNSELING}

Website: http://ojs.ejournal.id/index.php/ijec

Permalink: http://ojs.ejournal.id/index.php/ijec/article/view/116

How to cite (APA): Widiastuti, N. (2017). Aspirasi karier siswa SMA berdasarkan status sosial ekonomi dan gender. Indonesian Journal of Educational Counseling, 1(2), 109-128.

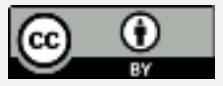

This is an open access article distributed under the terms of the Creative Commons Attribution 4.0 International License, which permits unrestricted use, distribution, and reproduction in any medium, provided the original work is properly cited.

\section{PENDAHULUAN}

Perkembangan karier merupakan salah satu aspek perkembangan individu yang bersifat sangat kompleks karena mengandung penggabungan dari banyak faktor dan bercirikan perubahan, serta merupakan bagian penting dalam perencanaan hidup (Winkel, 2010: 624). Salah satu faktor yang mempengaruhi perkembangan karier individu adalah aspirasi karier. Aspirasi karier dipandang sebagai refleksi dari self efficacy dan mediator penting dari motivasi dan pengembangan karier. Aspirasi karier juga dapat diartikan sebagai suatu harapan dalam pemilihan karier.

Aspirasi karier merupakan salah satu faktor yang mempengaruhi kematangan karier. Individu harus membentuk aspirasi karier dalam konteks kemampuan, potensi atau kapasitas, serta penerimaan terhadap situasi dan kenyataan di

\footnotetext{
${ }^{1}$ Departemen Psikologi Pendidikan dan Bimbingan, FIP Universitas Pendidikan Indonesia.
} 
sekitar individu untuk mencapai kematangan karier. Aspirasi karier mengarahkan tingkah laku individu untuk mencapai karier yang menjadi harapan atau cita-citanya. Aspirasi karier dapat membantu peserta didik untuk memilih sekolah lanjutan yang sesuai degan kemampuan dan potensi yang dimiliki peserta didik.

Menurut Giznberg (Santrock, 2003: 483) seseorang mulai memiliki aspirasi karier sebenarnya sudah di mulai pada usia dini, tetapi aspirasi karier tersebut masih bersifat fantasi di usia 11 hingga 17 tahun, pada usia sekitar 17 tahun atau pada usia tersebut adalah saat remaja duduk di bangku SMA, aspirasi karier individu mulai realistis, individu mulai menyesuaikan dengan keadaan dan kemampuan mereka. Sebab pada usia tersebut adalah sebuah transisi dari tahap fantasi masa kecil ke tahap pengambilan keputusan realistis dari masa dewasa awal.

Super (Bakar, A., \& Mohamed, S., 2004) mengindikasikan bahwa remaja berada pada tahap yang sangat penting dari "exploring" dan "crystallizing" pilihan karier mereka. Peserta didik pada tingkat SMA berada dalam tahap transisi dari remaja menuju dewasa. Dalam prosesnya, mereka akan menghadapi permasalahan terkait dengan pemilihan pendidikan dan karier setelah menyelesaikan pendidikan SMA. Mereka harus menentukan pilihan antara bekerja, melanjutkan kuliah, atau pilihan lainnya seperti mengambil program kursus keahlian. Sementara itu di Indonesia sendiri, terdapat proses peminatan dari mulai peserta didik memasuki jenjang SMA/MA/SMK. Peminatan peserta didik merupakan suatu proses pengambilan pilihan dan keputusan oleh peserta didik dalam bidang keahlian yang didasarkan atas pemahaman potensi diri dan peluang yang ada.

Conroy dan Empson (Bakar \& Mohamed, 2004) menyebutkan bahwa remaja memiliki aspirasi karier yang tidak realistik. Banyak yang percaya bahwa aspirasi karier merupakan faktor penting untuk pencapaian kedepannya. Namun, jika hanya aspirasi yang tinggi tidak menjamin pencapaian pendidikan yang tinggi pula.

Pada penelitian yang di lakukan Rahayu (1999) menunjukkan tidak ada perbedaan aspirasi karier antara remaja laki-laki dan remaja perempuan yang mempunyai inteligensi tinggi. Hal tersebut disebabkan oleh beberapa faktor antara lain kesempatan pendidikan yang diberikan oleh orang tua sekarang sama antara anak laki-laki dan anak perempuan, serta adanya persamaan antara pria dan wanita dalam masyarakat.

Dalam penelitian Peter A. Creed, Oi Yin Wong dan Michelle Hood (2009: 11) tidak ada perbedaan yang signifikan dan kompleks berdasarkan gender yang ditemukan berkaitan dengan cita-ata atau harapan pekerjaan. Dalam penelitian 
ini ditemukan bahwa aspirasi dan harapan karier siswa tidak sesuai satu sama lain, sementara gender tidak memiliki keterkaitan dengan aspirasi karier siswa.

Sementara itu, penelitian Nailil Faridah (2014: 65) menunjukkan bahwa terdapat hubungan positif yang signifikan antara aspirasi karier dengan kematangan vokasional pada siswa di SMK Walisongo Gempol Pasuruan, Hal ini mengandung pengertian semakin tinggi aspirasi karier seorang siswa maka semakin tinggi pula tingkat kematangan vokasional mereka.

Berdasarkan hasil penelitian Elok Zakiyatus Sifah tahun 2015 menunjukkan terdapat pengaruh efikasi diri terhadap aspirasi karier secara positif dan signifikan, yang berarti efikasi diri dapat memprediksikan aspirasi karier. Hal ini menunjukkan bahwa semakin tinggi effikasi peserta didik maka semakin tinggi pula kesempatan untuk memprediksi aspirasi karier peserta didik tersebut.

Status sosioekonomi dipandang sebagai pengelompokan individu berdasarkan kesamaan karakteristik pekerjaan, pendidikan serta status sosioekonomi menunjukkan adanya ketidak setaraan terentu dalam masyarakat Santrock (2007: 282). Brown dan Lent (2005: 131-154) menyatakan bahwa status sosial ekonomi mempengaruhi aspirasi kerja dalam banyak cara (misalnya, melalui akses diferensial dan paparan keterampilan dan efikasi-bangunan pengalaman).

Gender adalah karakteristik yang digunakan sebagai dasar untuk mengidentifikasi perbedaan antara pria dan wanita dalam hal kondisi sosial dan budaya, nilai-nilai dan perilaku, mentalitas, emosi, dan faktor non biologis lainnya. Teori-teori psikologi sosial tentang perilaku karier menekankan bagaimana budaya, gender, dan peristiwa kehidupan berinteraksi dengan preferensi karier individu untuk menentukan aspirasi karier dan pilihan (Brown \& Lent, 2005: 131-154).

Bimbingan konseling sebagai bagian integral dari pendidikan yang berfungsi untuk membantu siswa dalam mencapai perkembangan yang optimal, salah satunya membantu siswa mencapai tugas perkembangan karier yakni dalam pengambilan keputusan karier yang sesuai dengan apa yang siswa inginkan. Konselor sekolah mempunyai peranan yang lebih besar dibandingkan dengan personil sekolah lain untuk membantu siswa dalam proses pengambilan keputusan karier untuk masa depannya. Peran bimbingan dan konseling juga sangat penting untuk memberikan informasi terkait dengan berbagai pilihan karier yang ada sehingga siswa memiliki banyak referensi dalam proses pengambilan keputusan kariernya.

Penelitian sebelumnya oleh Rahayu tahun 1999 menunjukkan bahwa tidak terdapat perbedaan aspirasi karier antara remaja laki-laki dan perempuan itu 
menunjukkan bahwa gender tidak mempengaruhi aspirasi karier sekarang ini. Selain itu hasil penelitian Peter A. Creed, Oi Yin Wong dan Michelle Hood tahun 2009 mendukung hasil penelitian sebelumnya yakni tidak ada perbedaan yang signifikan dan kompleks aspirasi karier berdasarakan gender. Penelitian Nailil Faridah tahun 2014 pun menunjukkan bahwa terdapat hubungan positif yang signifikan antara aspirasi karier dengan kematangan vokasional. Kemudian penelitian Elok Zakiyatus Sifah tahun 2015 menunjukkan bahwa effikasi diri berpengaruh positf terhadap aspirasi karier individu.

Berdasarkan studi pendahuluan di Sekolah Menegah Atas Negeri 1 Batujajar dengan melakukan wawancara kepada Guru BK, saat ini masih ada peserta didik yang masih bingung dalam menentukan rencana masa depan mereka masing-masing sehingga hal itu berdampak pada kemampuan peserta didik dalam melakukan perencaan pemilihan karier kedepannya.

Fokus permasalahan karier yang dibahas dalam penelitian ini adalah aspirasi karier peserta didik berdasarkan status sosial ekonomi dan gender kelas $X$ SMA Negeri 1 Batujajar sebagai bahan pertimbangan untuk melanjutkan pendidikan baik pemilihan jurusan maupun kelanjutan pendidikan ke perguruan tinggi serta pekerjaan yang sesuai dengan juruan yang dipilih.

\section{METODE}

Penelitian dilaksanakan di Sekolah Menengah Atas Negeri 1 Batujajar yang berlokasi di Jalan Raya Selacau, Kecamatan Batujajar, Kabupaten Bandung Barat. Populasi penelitian ini adalah peserta didik kelas X SMA Negeri 1 Batujajar Tahun Ajaran 2015/2016 dengan jumlah 480 peserta didik. Pertimbangan dalam menentukan populasi penelitian dikelas X SMA Negeri 1 Batujajar diantaranya yaitu: 1) Peserta didik kelas $X$ sudah mampu berpikir mengenai karier secara lebih spesifik dan realistik dibandingkan dengan anak yang berada pada tingkat dibawahnya; 2) Peserta didik kelas $X$ berada pada rentang usia 14 tahun keatas, menurut Gottfredson (Anderson \& Vandehey, 2006) berada pada tahap terakhir yakni orientasi internal dimana peserta didik sedang berjuang untuk memahami apa kepentingan, kemampuan dan nilainilai mereka yang sebenarnya; 3) Lokasi sekolah yang strategis sehingga demografi tempat tinggal peserta didik di SMAN 1 Batujajar lebih beragam serta berasal dari kondisi sosial ekonomi yang beragam pula.

Teknik pengambilan sampel yang digunakan dengan istilah purposive sampling, dengan arti bahwa setiap anggota populasi yang dipilih memiliki karakteristik-karakteristik tertentu (Creswell, 2010: 202). Karakteristik yang dimaksud dalam penelitian ini adalah gender dan status sosial ekonomi. 
Dengan demikian sampel yang diperoleh sebanyak 234 peserta didik yang memenuhi karakteristik yang telah ditentukan.

Pendekatan yang digunakan dalam penelitian ini adalah pendekatan kuantitatif. Creswell (2010: 5) menyebut bahwa penelitian kuantitatif merupakan penelitian dengan mengunakan metode-metode tertentu untuk menguji teori-teori dengan cara meneliti hubungan antar variabel. Metode yang digunakan adalah deskriptif, yakni mendeskripsikan profil aspirasi karier peserta didik berdasarkan faktor demografi. Menurut Nana Sudjana dan Ibrahim (2007: 64) yang dimaksud penelitian deskriptif adalah "penelitian yang berusaha mendeskripsikan suatu gejala, peristiwa, kejadian yang terjadi pada saat sekarang".

Jenis instrumen yang digunakan adalah angket tertutup dengan bentuk cheklist. Memiliki pilihan jawaban sehingga responden hanya tinggal memilih jawaban yang telah disediakan, disusun berdasarkan model skala Likert. Jumlah alternatif respon terdiri dari lima alternatif. Untuk memperoleh data mengenai deskripsi aspirasi karier, untuk mengungkapnya menggunakan angket pengungkap aspirasi karier. Pengembangan instumen diawali dengan pembuatan definisi operasional variabel dan kisi-kisi alat pengumpul data yang dikembangkan dari variabel-variabel penelitian. Pembuatan kisi-kisi alat pengumpulan data dapat dilakukan dengan menelaah berbagai literatur sehingga menjadi rancangan pokok instrumen.

Pada alat ukur, setiap item diasumsikan memiliki nilai 1-5 dengan bobot tertentu. Bobotnya ialah: 1) Untuk pilihan jawaban sangat sesuai (SS) memiliki skor 5 pada pernyataan positif atau skor 1 pada pernyataan negatif; 2) Untuk pilihan jawaban sesuai (S) memiliki skor 4 pada pernyataan positif atau skor 2 pada pernyataan negatif; 3) Untuk pilihan jawaban ragu (R) memiliki skor 3 pada pernyataan positif atau skor 3 pada pernyataan negatif; 4) Untuk pilihan jawaban tidak sesuai (TS) memiliki skor 2 pada pernyataan positif atau skor 4 untuk pernyataan negatif; 5) Untuk pilihan jawaban sangat tidak sesuai (STS) memiliki skor 1 pada pernyataan positif atau skor 5 untuk pernyataan negatif.

Berdasarkan hasil uji kelayakan berdasarkan penilaian pakar, kisi-kisi instrumen untuk mengungkap kompetensi karier peserta didik dapat dilihat pada Tabel 1.

Untuk memastikan validitas dan reliabilitas instrumen, instrumen yang dipergunakan terlebih dahulu diujicobakan terhadap responden yang sama dengan responden yang telah ditentukan untuk sumber data penelitian. Uji coba instrumen dilaksanakan sebagai prosedur penempatan sejumlah alternatif respon tiap item pada suatu kontinum kuantitatif sehingga didapatkan angka sebagai skor masing-masing alternatif respon. 
Tabel 1. Kisi-kisi Instrumen Aspirasi Karier Peserta Didik Setelah Uji Kelayakan

\begin{tabular}{cl}
\hline Aspek & \multicolumn{1}{c}{ Indikator } \\
\hline 1. Sikap & Memiliki minat terkait pendidikan lanjutan dan pekerjaan \\
\cline { 2 - 2 } & $\begin{array}{l}\text { Memiliki motivasi terkait dengan pencapaian pendidikan lanjutan } \\
\text { dan pekerjaan }\end{array}$ \\
\cline { 2 - 2 } & $\begin{array}{l}\text { Memiliki Ide-ide alternatif mengenai pendidikan lanjutan dan } \\
\text { pekerjaan }\end{array}$ \\
\hline 2. Perilaku & Mempersiapkan Perencanaan aktual \\
\cline { 2 - 2 } & Memilih strategi atau langkah-langkah yang akan dilakukan \\
\cline { 2 - 2 } & Berkerja keras dalam upaya mencapai tujuan yang telah ditentukan \\
\hline
\end{tabular}

Instrumen pengungkap data ini diujicobakan kepada 234 orang responden dengan sistem built-in, artinya uji coba instrumen sekaligus pengumpulan data, kemudian data yang diperoleh dihitung nilai validitas dan reliabilitasnya selanjutnya butir digunakan sebagai sumber data.

Setelah dilakukan uji coba instrumen, selanjutnya skor setiap item pernyataan pada instrumen diolah untuk mengetahui vailiditas tiap item dan juga reliabilitas dari instrumen. Validitas yang digunakan dalam peneltian ini adalah validitas konstruk dan konten. Validitas konten berkaitan dengan ketepatan suatu alat ukur ditinjau dari isi alatukur tersebut. Sementara validitas konstruk berkaitan dengan konstruksi bidang ilmu yang akan diuji validitas alat ukurnya.

Uji validitas Pengujian validitas instrumen dalam penelitian ini dilakukan dengan analisis faktor, yaitu dengan mengkorelasikan antara skor item instrumen dengan rumus Pearson. Berdasarkan pengolahan data, hasil uji validitas menunjukkan bahwa dari 40 butir pernyataan dari aspirasi karier peserta didik, 38 butir pernyataan dinyatakan valid. Indeks validitas instrumen bergerak di antara $0.065-0.620$ dengan distribusi (tabel t) untuk $\alpha=0,01$.

Pengujian reliabilitas instrumen aspirasi karier peserta didik dalam penelitian ini menggunakan rumus Cronbach's Alpha dengan bantuan program SPSS 21.0. Berdasarkan hasil pengolahan data, diperoleh nilai reliabilitas sebesar 0,831 . Dengan demikian, data yang dihasilkan instrumen penelitian ini menunjukkan reliabilitas yang sangat andal. Artinya instrumen yang digunakan baik dan dapat dipercaya sebagai alat pengumpul data Aspirasi karier peserta didik kelas X SMA.

Setiap item pernyataan dalam instrumen kompetensi karier ini menggunakan skala likert dengan lima alternatif jawaban, yaitu Sangat Sesuai (SS), Sesuai (S), Kurang Sesuai (KS), Tidak Sesuai (TS), dan Sangat Tidak Sesuai (STS). Penentuan skala likert dapat dilakukan dengan cara apriori, yaitu pemberian skor dengan cara ditentukan dan aposteritori, yaitu pemberian skor berdasarkan hasil uji coba. Penyekoran data pada penelitian ini mengacu pada 
penentuan skor skala likert dengan cara penyekoran aposteritori, yaitu menentukan skor dengan menguji skor pada setiap item pernyataan (Subino, dalam Zuraida 2015: 56). Adapun langkah-langkah menguji pola penyekoran skala Likert aposteritori dijelaskan oleh Suryabrata (2005: 188) sebagai berikut: 1) Menghitung frekuensi (f) jawaban setiap item pernyataan; 2) Menghitung presentase setiap frekuensi jawaban untuk mengetahui nilai proporsi $(p) ; 3)$ Menghitung persentil kumulatif (cp); 4) Mencari nilai tengah dari persentil kumulatif (mid point $\mathrm{cp}$ ); 5) Mengkonversi nilai mid point $\mathrm{cp}$ menjadi nilai $\mathrm{z}$ dengan menggunakan fungsi NORMSINV; 6) Untuk menghilangkan tanda negatif pada skala, nilai $z$ dikoreksi menjadi $z+$ dengan cara menambahkan nilai mutlak dari nilai $z$ terkecil. Pola penyekoran skala Likert dalam penelitian ini dilakukan pembulatan. Pola skor untuk nomor item pernyataan yang lainnya telah ditentukan.

Penyekoran dimaksudkan untuk memudahkan analisis data menggunakan teknik statistik. Adapun langkah-langkah untuk menentukan batas ideal kriteria skor aspirasi karier peserta didik kelas X SMA adalah sebagai berikut: 1) Menghitung skor total setiap responden; 2) Menghitung rata-rata dari skor total responden $(\mu)$; 3 ) Menghitung standar deviasi dari skor total responden $(\sigma) ; 4)$ Mengelompokkan data menjadi tiga kategori

Setelah dirumuskan batas lulus ideal, data tentang aspirasi karier dikelompokkan ke dalam lima kategori yaitu sangat tinggi, tinggi, sedang, rendah sangat rendah, seperti pada Tabel 2. Pengelompokan ini bertujuan untuk memperoleh profil aspirasi karier peserta didik sebagai dasar penyusunan program bimbingan karier peserta didik kelas X SMA Negeri Batujajar Tahun Ajaran 2015/2016.

Tabel 2. Kategorisasi Aspirasi Karier

\begin{tabular}{ccc}
\hline Kategori & Batas Ideal & Hasil Perhitungan \\
\hline Tinggi & $x>(\mu+1,0 \sigma)$ & $\mathrm{x}>2,69$ \\
\hline Sedang & $(\mu+1,0 \sigma) \leq x \leq(\mu+1,0 \sigma)$ & $2,05 \leq \mathrm{x} \leq 2,68$ \\
\hline Rendah & $x<(\mu-1,0 \sigma)$ & $\mathrm{x}<2,04$ \\
\hline
\end{tabular}

\section{HASIL DAN PEMBAHASAN}

Berdasarkan hasil pengumpulan dan pengolahan data, dengan jumlah responden sebanyak 234 peserta didik, diperoleh nilai rerata aspirasi karier sebesar 2,38, median sebesar 2,35, modus sebesar 1,54, simpangan baku sebesar 0,32 , dengan nilai maksimum sebesar 3,46 dan nilai minimum sebesar 1,54. Dengan demikian, profil aspirasi karier peserta didik kelas X SMA Negeri 1 Batujajar yang diperoleh berada pada kategori sedang. Artinya peserta didik 
memiliki kemampuan yang cukup baik terkait dengan dengan aspirasi kariernya baik dalam komponen sikap maupun perilakunya. Meskipun berada pada kategori yang sama, namun skor yang diperoleh beragam. Nilai median sebesar 2,35 menunjukkan bahwa 50\% data lebih kecil dari 2,35 dan 50\% data lebih besar dari 2,35. Nilai modus sebesar 1,54 menunjukkan bahwa sebagian besar peserta didik kelas X SMA Negeri 1 Batujajar memperoleh nilai 1,54 dan nilai tersebut menunjukkan kategori rendah pada penelitian aspirasi karier.

Dalam aspirasi karier terdapat dua komponen yang harus dikuasai oleh peserta didik, yakni komponen sikap dan komponen perilaku. Nilai rerata tertinggi berada pada komponen sikap yaitu sebesar 2,49 yang berada pada kategori sedang, dengan nilai simpangan baku sebesar 0,35, nilai modus sebesar 2,26, dan nilai median sebesar 2,48 dengan nilai maksimum sebesar 3,44 dan nilai minimum sebesar 1,47. Pada komponen sikap ini, secara umum peserta didik memperoleh nilai sebesar 2,48 , sebanyak $50 \%$ data lebih kecil dari 2,36 dan $50 \%$ data lebih besar 2,36.

Sementara itu, komponen perilaku memiliki nilai rerata lebih kecil dari komponen sikap yakni sebesar 2,27, dengan nilai simpangan baku sebesar 0,34 , nilai modus sebesar 2,20 , dan nilai median sebesar 2,23 dengan nilai maksimum sebesar 3,58 dan nilai minimun sebesar 1,31 . secara umum peserta didik memperoleh nilai sebesar 2,25 , sebanyak $50 \%$ data lebih kecil dari 2,23 dan $50 \%$ data lebih besar 2,23.

Kecenderungan komponen aspirasi karier kelas X SMAN 1 Batujajar dapat dilihat pada Tabel 3.

Tabel 3. Kecenderungan Komponen Aspirasi Karier Kelas $X$

\begin{tabular}{ccc}
\hline Komponen & Sikap & Perilaku \\
\hline $\mathrm{N}$ & 234 & 234 \\
\hline Rerata & 2,49 & 2,27 \\
\hline Std. Deviasi & 0,35 & 0,34 \\
\hline Modus & 2,26 & 2,20 \\
\hline Median & 2,48 & 2,23 \\
\hline Nilai Maks. & 3,44 & 3,58 \\
\hline Nilai Min. & 1,47 & 1,31 \\
\hline Kategori & Sedang & Sedang
\end{tabular}

Pada kelompok tingkat pendidikan dasar, nilai rerata komponen sikap yakni sebesar 2,39, kemudian pada aspek perilaku sebesr 2,20. Nilai rerata kelompok pendidikan dasar ini lebih kecil daripada dua kelompok lainnya yakni kelompok pendidikan menengah dengan nilai rerata komponen sikap sebesar 2,55 dan komponen perilaku sebesar 2,30. Serta kelompok pendidikan tinggi dengan nilai rerata aspek sikap sebesar 2,51 dan aspek perilaku sebesar 2,33. 
Pada komponen sikap kelompok peminatan menengah memiliki nilai rerata paling besar sedangkan pada komponen perilaku kelompok pendidikan tinggi yang memiliki nilai rerata lebih besar. Sementara itu, untuk kelompok tingkat pendidikan dasar memiliki nilai rerata lebih kecil baik dari komponen sikap maupun komponen perilaku dari kedua kelompok lainnya. Meskipun terdapat keragaman dalam nilai rerata tiap kelompok, namun tiap kelompok masik berada pada kategori yang sama yakni sedang, seperti dilihat pada Tabel 4.

Tabel 4. Kecenderungan Komponen Aspirasi Karier Berdasarkan Pendidikan Terakhir Ayah

\begin{tabular}{cllcc}
\hline Komponen & \multicolumn{1}{c}{ Tingkat Pendidikan } & N & Rerata & Kategori \\
\hline \multirow{5}{*}{ Sikap } & Pendidikan Prasekolah & - & - & - \\
\cline { 2 - 5 } & Pendidikan Dasar & 73 & 2,39 & Sedang \\
\cline { 2 - 5 } & Pendidikan Menengah & 128 & 2,55 & Sedang \\
\cline { 2 - 5 } & Pendidikan Tinggi & 33 & 2,51 & Sedang \\
\hline \multirow{3}{*}{ Perilaku } & Pendidikan Prasekolah & - & - & - \\
\cline { 2 - 5 } & Pendidikan Dasar & 73 & 2,20 & Sedang \\
\cline { 2 - 5 } & Pendidikan Menengah & 128 & 2,30 & Sedang \\
\cline { 2 - 5 } & Pendidikan Tinggi & 33 & 2,33 & Sedang \\
\hline
\end{tabular}

Bedasarkan tingkat atau besarnya pendapatan orangtua, dapat dilihat pada Tabel 4. Kelompok 5 memiliki nilai rerata lebih besar baik dari komponen sikap dan perilaku daripada kelompok pendapatan lainnya. Pada komponen sikap kelopok pendapatan satu dan dua memiliki nilai rerata yang sama, namun pada komponen perilaku kelompok pendapatan dua memiliki nilai rerata yang lebih besar daripada kelompok pendapatan satu.

Pada komponen sikap, kelompok pendapatan 5 berada pada kategori tinggi dengan nilai rerata sebesar 3,03, dan untuk kelompok pendapatan lainnya baik dari komponen sikap maupun perilaku berada pada kategori yang sama, yakni sedang dengan nilai rerata yang beragam. Seperti dapat dilihat pada Tabel 5.

Tabel 5. Kecenderungan Komponen Aspirasi Karier Berdasarkan Penghasilan Orangtua

\begin{tabular}{cllccc}
\hline Komponen & \multicolumn{1}{c}{ Penghasilan } & N & Rerata & Kategori \\
\hline \multirow{5}{*}{ Sikap } & Klp 1. ( $\leq$ Rp500.000 $)$ & 22 & 2,41 & Sedang \\
\cline { 2 - 5 } & Klp 2. (Rp 500.000 s.d. 1 juta) & 59 & 2,41 & Sedang \\
\cline { 2 - 5 } & Klp 3. (1 juta rupiah s.d. 3 juta) & 93 & 2,49 & Sedang \\
\cline { 2 - 5 } & Klp 4. (3 juta rupiah s.d. 6 juta) & 57 & 2,58 & Sedang \\
\cline { 2 - 5 } & Klp 5. (> 6 juta rupiah) & 2 & 3,03 & Tinggi \\
\hline \multirow{5}{*}{ Perilaku } & Klp 1. ( Rp500.000 $)$ & 22 & 2,15 & Sedang \\
\cline { 2 - 5 } & Klp 2. (Rp 500.000 s.d. 1 juta) & 59 & 2,25 & Sedang \\
\cline { 2 - 5 } & Klp 3. (1 juta rupiah s.d. 3 juta) & 93 & 2,24 & Sedang \\
\cline { 2 - 5 } & Klp 4. (3 juta rupiah s.d. 6 juta) & 57 & 2,36 & Sedang \\
\cline { 2 - 5 } & Klp 5. (>6 juta rupiah) & 2 & 2,82 & Tinggi \\
\hline
\end{tabular}


Antara laki-laki dan perempuan terdapat kesamaan kategori mengenai komponen aspirasi karier. Secara total nilai rerata tidak jauh berbeda untuk laki-laki sebesar 2,36 dan untuk perempuan sebesar 2,39 keduanya berada pada kategori sedang, seperti ditampilkan pada Tabel 6.

Tabel 6. Kecenderungan Komponen Aspirasi Karier berdasarkan Gender

\begin{tabular}{lllll}
\hline Gender & $\mathrm{N}$ & Komponen & Rerata & Kategori \\
\hline Laki-laki & 80 & Sikap & 2,45 & Sedang \\
\hline & & Perilaku & 2,28 & Sedang \\
\hline Perempuan & 154 & Sikap & 2,52 & Sedang \\
\hline & & Perilaku & 2,27 & Sedang \\
\hline
\end{tabular}

Perbandingan aspirasi karier peserta didik antara laki-laki dan perempuan menunjukkan signifikan sebesar 0,531, menunjukkan bahwa tidak terdapat perbedaan aspirasi karier antara laki-laki dan perempuan.

Pada komponen sikap terdapat tiga indikator, yang di antaranya adalah memiliki minat terkait pendidikan lanjutan dan pekerjaan, memiliki motivasi terkait dengan pencapaian pendidikan lanjutan dan pekerjaan serta memiliki ide-ide alternatif mengenai pendidikan lanjutan dan pekerjaan. Hasil pengolahan data menunjukkan bahwa indikator memiliki minat terkait pendidikan lanjutan dan pekerjaan dengan nilai rerata sebesar 2,38, simpangan baku sebesar 0,48, modus sebesar 2,50 menunjukkan bahwa sebagian besar peserta didik memperoleh nilai 2,50 pada indikator memiliki minat terkait pendidikan lanjutan dan pekerjaan, dan median sebesar 2,50 menunjukkan bahwa $50 \%$ data lebih kecil 2,50 dan 50\% data lebih besar dari 2,50. Dengan nilai maksimum sebesar 3,50 dan nilai minimum sebesar 0,50. Nilai rerata memiliki motivasi terkait dengan pencapaian pendidikan lanjutan dan pekerjaan sebesar 2,29, simpangan baku sebesar 0,42, modus sebesar 2,14 berarti bahwa secara umum peserta didik memperoleh nilai 2,14 pada indikator memiliki motivasi terkait dengan pencapaian pendidikan lanjutan dan pekerjaan dan median sebesar 2,29 menunjukkan bahwa setengah data lebih besar dari 2,29 dan setengah data lebih kecil dari 2,29. Indikator kedua pada komponen sikap ini memiliki nilai maksimum sebesar3,43 dan nilai minimum sebesar 1,14. Sedangkan indikator memiliki motivasi terkait dengan pencapaian pendidikan lanjutan dan pekerjaan memiliki nilai rerata sebesar 2,70 , perolehan simpangan baku sebesar 0,67 , modus sebesar 2,67 artinya sebagian besar peserta didik memperoleh nilai 2,67 pada indikator ide-ide mengenai pendidikan lanjutan dan pekerjaan, dan median sebesar 2,67 menunjukkan bahwa setengah data lebih besar dari 2,67 dan setengah data lebih kecil dari 2,67. Ketiga indikator dari komponen sikap termasuk kedalam kategori sedang. 
Komponen kedua yakni komponen perilaku juga memiliki tiga indikator seperti komponen sikap yakni memiliki perencanaan yang aktual dalam menentukan pendidikan lanjutan dan pekerjaan, memilih strategi atau langkah-langkah yang akan dilakukan untuk mencapai pendidikan lanjutan dan pekerjaan yang diinginkan, dan berkerja keras dalam upaya mencapai tujuan yang telah ditentukan. Berdasarkan hasil pengolahan data nilai rerata untuk indikator pertama pada aspek perilaku ini yakni memiliki perencanaan yang aktual dalam menentukan pendidikan lanjutan dan pekerjaan sebesar 2,25, dengan simpangan baku 0,44 , modus 2,00 yang menunjukkan bahwa sebagian besar peserta didik memperoleh nilai 2,00, median sebesar 2,22 yang menunjukkan bahwa setengah data lebih besar dari 2,22 dan setengah data lebih kecil dari 2,22 , serta nilai maksimum 3,78 dan nilai minimum sebesar 1,33. Indikator memiliki perencanaan yang aktual dalam menentukan pendidikan lanjutan dan pekerjaan terdapat dalam kategori sedang. Sementara itu, pada indikator memilih strategi atau langkah-langkah yang akan dilakukan untuk mencapai pendidikan lanjutan dan pekerjaan yang diinginkan memiliki nilai rerata sebesar 2,00, nilai simpangan baku sebesar 0,33 , median 2,00 yang menunjukkan bahwa setengah data lebih besar dari 2,00 dan setengah data lebih kecil dari 2,00, nilai modus sebesar 2,10 yang menunjukkan bahwa sebagian besar peserta didik memperoleh nilai 2,10, serta nilai maksimum sebesar 3,10 dan nilai minimum sebesar 1,10. Maka dari itu, untuk indikator memilih strategi atau langkah-langkah yang akan dilakukan untuk mencapai pendidikan lanjutan dan pekerjaan berada pada kategori rendah. Dan nilai rerata indikator terakhir yakni berkerja keras dalam upaya mencapai tujuan yang telah ditentukan sebesar 2,35, nilai simpangan baku sebesar 0,52, modus sebesar 2,20 yang menunjukkan bahwa sebagian besar peserta didik memperoleh nilai 2,20, nilai median sebesar 2,20 yang menunjukkan bahwa setengah data lebih besar dari 2,20 dan setengah data lebih kecil dari 2,20, dengan nilai maksimum sebesar 3,80 dan nilai minimum sebesar 0,80 . Maka untuk indikator berkerja keras dalam upaya mencapai tujuan yang telah ditentukan berada pada kategori sedang.

Kecenderungan indikator dari setiap komponen aspirasi karier berdasarkan pengelompokam pendidikan terakhir orangtua semuanya berada pada kategori sedang dengan nilai rerata yang cukup beragam. Pada beberapa indikator kelompok pendidikan tinggi memiliki nilai rerata paling besar diantara kelompok pendidikan lainnya, namun pada indikator lainnya kelompok pendidikan menengah juga memiliki nilai rerata lebih besar. Sementara itu, untuk kelompok pendidikan dasar memiliki nilai rerata paling kecil pada semua indikator setiap komponen. Meskipun demikian, perbedaan nilai rerata tiap kelompok tingkat pendidikan tidak memiliki perbedaan yang terlalu besar. 
Berdasarkan pengelompokan penghasilan orangtua, untuk kelompok penghasilan 5 pada indikator memiliki ide-ide alternatif mengenai pendidikan lanjutan dari komponen sikap dan pekerjaan dan mempersiapkan perencanaan aktual dari komponen perilaku, keduanya berada pada kategori tinggi dengan rerata masing-masing yakni 3,37 dan 3,14. Seentara itu pada indikator lainnya dari masing-masing komponen, semua kelompok berada dalam kategori sedang. Kelompok penghasilan 1 memiliki nilai rerata paling kecil dari setiap indikator baik dari aspek sikap maupun perilaku, namun masih berada pada kategori yang sama dengan yang lainnya yakni kategori sedang.

Berdasarkan pengelompokan gender, semua indikator setiap komponen berada pada kategori sedang baik dari elompok gender laki-laki maupun perempuan. Dan untuk nilai rerata cukup beraga meskipun pada beberapa inikator memiliki nilai rerata yang sama.

Penelitian ini menunjukkan bahwa secara umum aspirasi peserta didik berada pada kategori cukup. Artinya peserta didik masih memerlukan pengembangan aspirasi karier kearah yang lebih realistis yakni dimana peserta didik sudah mampu membuat perncanaan dan strategi-strategi untuk mecapai karier yang diharapkan. Menurut super apsirasi karier merupakan cerminan dari identitas karier atau konsep diri karier individu. Aspirasi karier mengacu pada tujuan atau intensi individu yang diekspresikan melaui pekerjaan terkait dan juga termasuk komponen motivasi yang bukan hanya dalam minat.

Hasil penelitian menunjukkan sebanyak $15,0 \%$ berada pada kategori tinggi. Kategori tinggi menunjukkan bahwa peserta didik sudah mempertimbangkan kepentingan, kapasitas, dan nilai-nilai sebagai kriteria penting untuk mempersempit pilihan karier. Selain itu, peserta didk juga sudah mempertimbangkan perencanaa-perencanaan agar dapat mencapai tujuan yang telah ditentukan.

Menurut Gottfredson peserta didik kelas X berada pada tahapan orientasi iternal pada konsep circumtance. Berdasarkan psikologi perkembangan, individu atau remaja pada tahapan ini sedang mengalami krisis identitas, dimana remaja berjuang untuk memahami apa minat mereka, kemampuan, dan nilai-nilai yang sebenarnya. Pada tahapan ini remaja juga sudah mulai mempertimbangkan keentingan, kapasitas dan nilai-nilai sebagai kriteria penting untuk mempersempit pilihan karier mereka.

Kategori sedang menunjukkan bahwa individu masih belum terlalu mempertimbangkan kepentingan, kapasitas, dan nilai-nilai sebagai kriteria penting untuk mempersempit pilihan karier, pada penelitian ini kategori sedang memiliki persentase paling tnggi yakni sebesar $71,8 \%$. 
Peserta didik yang termasuk kedalam kategori rendah sebanyak 13,2\%. Kategori rendah menunjukkan bahwa peserta didik belum mempertimbangkan kepentingan, kapasitas, dan nilai-nilai sebagai kriteria penting untuk mempersempit pilihan karier. Sehingga peserta didik cenderung hanya memikirkan tentang minat yang dimiliki tanpa mempertimbangkan kemampuan, kesempatan dan juga belum memiliki perencanaan yang realistis untuk mencapi tujuannya.

Untuk dapat mencapai kematangan karier maka individu perlu mengidentifik,asi dan mengeksplorasi keadaan dirinya sendiri dan lingkungan sekitar yang memengaruhi perkembangan karier, selanjutnya individu tersebut melakukan penyesuaian antara keadaan dirinya dan keadaan lingkungan. Namun melihat hasil yang diperoleh, dapat disebabkan individu yang belum mengetahui secara pasti mengenai keadaan dirinya dan lingkungan pendidikan atau pekerjaan yang akan dijalani sehingga individu belum dapat melakukan penyesuaian dan menentukan alternatif karier. Remaja awal cenderung untuk mengekspresikan aspirasi yang mencerminkan keinginan untuk memiliki pekerjaan masa depan yang berkaitan dengan prestise yang tinggi dan status sosial yang tinggi, tanpa memikirkan apakah mereka memiliki kesempatan yang realistis untuk mencapai tujuan-tujuan tersebut (Gottfredson, 2005)

Jika dilihat dari perspektif pembelajaran sosial, terjadinya interaksi antara kognitif, perilaku, dan lingkungan akan memberikan pembelajaran bagi individu. Melalui pembelajaran sosial, individu mulai untuk menilai keadaan dirinya, pekerjaan atau pendidikan yang sesuai dengan keadaan diri, dan lingkungan sosial yang mendukung. Setelah ia mendapatkan pemahaman dari apa yang telah dipelajari mengenai karier, maka aspirasi individu akan berubah menjadi realistik, dikarenakan adanya pertimbangan-pertimbangan yang di sesuaikan dengan kemampuan dan ketekunan individu untuk mencapai suatu prestasi sehingga kemungkinan aspirasi bisa tercapai semakin tinggi.

Kategori sedang dapat berubah menjadi rendah tanpa adanya upaya pengembangan yang terstruktur dan sistematis ke arah tinggi atau sangat tinggi. Individu yang memiliki aspirasi karier rendah cenderung mengalami keraguan karier atau bahkan tidak dapat mengambil keputusan karier secara tepat. Hal tersebut akan berdampak terhadap perkembangan karier individu selanjutnya.

Siswa SMA dalam fase remaja awal cenderung untuk mengekspresikan aspirasi yang mencerminkan keinginan untuk memiliki pekerjaan masa depan yang berkaitan dengan prestise yang tinggi dan status sosial yang tinggi, tanpa memikirkan apakah mereka memiliki kesempatan yang realistis untuk mencapai tujuan-tujuan tersebut (Gottfredson, 2005; Mau \& Bikos, 2000; 
Rojewski \& Yang, 1997). Dengan demikian, peserta didik yang memiliki aspirasi karier sangat tinggi akan maenunjukkan bahwa ia mampu menuasai komponen aspirasi karier baik dari komponen sikap maupun perilaku. Namun pada penelitian ini, nilai rerata peserta didik pada komponen-komponen aspirasi karier baik komponen sikap maupun perilaku berada pada kategori sedang.

Berdasarkan komponen sikap peserta didik yang masuk kategori tinggi sebesar $26,5 \%$. Kategori tinggi dalam komponen sikap ini menunjukkan bahwa peserta didik sudah memiliki minat terkait pendidikan lanjutan dan pekerjaan, memiliki motivasi terkait dengan pencapaian pendidikan lanjutan dan pekerjaan serta memiliki ide-ide alternatif mengenai pendidikan lanjutan dan pekerjaan. Sementara itu, peserta didik yang masuk pada kategori sedang sebanyak 63,2\%. Kategori sedang dalam komponen sikap ini menunjukkan bahwa peserta didik belum terlalu mengenal diri, dalam hal ini belum terlalu menunjukkan minatnya dalam bidang tertentu serta belum memiliki motivasi yang kuat untuk mencapai tujuannya. Peserta didik yang termasuk dala kategori rendah sebanyak $10,3 \%$. Kategori sedang dalam aspek sikap ini menunjukkan bahwa peserta didik belum memiliki minat terkait pendidikan lanjutan dan pekerjaan, memiliki motivasi terkait dengan pencapaian pendidikan lanjutan dan pekerjaan serta memiliki ide-ide alternatif mengenai pendidikan lanjutan dan pekerjaan.

Komponen perilaku peserta didik yang termasuk dalam kategori tinggi sebanyak $12,4 \%$, kategori sedang sebesar $63,7 \%$ dan kategori rendah sebesar $23,9 \%$. Kategori tinggi dalam komponen perilaku ini menunjukkan bahwa peserta didik memiliki perencanaan yang aktual dalam menentukan pendidikan lanjutan dan pekerjaan, memilih strategi atau langkah-langkah yang akan dilakukan untuk mencapai pendidikan lanjutan dan pekerjaan yang diinginkan, dan berkerja keras dalam upaya mencapai tujuan yang telah ditentukan. Pada komponen perilaku kategori sedang menunjukkan bahwa eserta didik belum memiliki perencanaan yang aktual dalam menentukan pendidikan lanjutan dan pekerjaan, strategi atau langkah-langkah yang akan dilakukan untuk mencapai pendidikan lanjutan dan pekerjaan yang diinginkan, dan belum berkerja keras dalam upaya mencapai tujuan yang telah ditentukan. Sementara itu, kategori rendah menunjukkan bahwa peserta didik tidak memiliki perencanaan yang aktual dalam menentukan pendidikan lanjutan dan pekerjaan, memilih strategi atau langkah-langkah yang akan dilakukan untuk mencapai pendidikan lanjutan dan pekerjaan yang diinginkan, dan tidak berkerja keras dalam upaya mencapai tujuan yang telah ditentukan.

Menurut Gottfredson "career choice is a developmental process begining in childhood; occupational aspiration reflect people efforts to implement their self 
concept; satisfaction with career choice depends oh how well then choice fits the self concept' (Anderson \& Vendehey, 2012). Proses pemlihan karier merupakan proses perkembangan yang dimulai sejak masa kanak-kanak, aspirasi karier menggambarkan upaya individu untuk menunjukkan konsep dirinya dan kepuasan yang diperoleh dalam karier tergantug pada kesesuaian pilihan karier dengan konsep diri. Namun hasil yang diperoleh dari penelitian aspirasi karier terhadap kelas $\mathrm{X}$ menunjukkan komponen sikap berada pada kategori sedang. Hal ini menunjukkan bahwa individu belum memiliki minat, motivasi, serta ide-ide yang sesuai dengan kemampuan yang dimiliki. Jika dilihat dari tahap perkembangannya, hal yang sangat wajar ketika peserta didik masih memiliki kategori cukup tada komponen sikap ini, karena peserta didik pada taham ini sedang mengalami masa krisis menurut psikologi perkembangan, selain itu komponen sikap pada aspirasi karier akan semakin matang dan akan menigkat seiring perkembangan individu.

Gottfredson (1981) mengemukakan bahwa pengembangan self-concept karier dikaitkan dengan proses pemeriksaan dan penghapusan alternatif pekerjaan, yang ia disebut batasan (circumscription). Pada dasarnya, individu semakin menghilangkan apa yang mereka anggap sebagai alternatif tidak dapat diterima untuk menciptakan ruang sosial atau zona mereka terhadap alternatif yang bisa diterima. Namun berdasarkan hasil yan didapatkan, komponen perilaku dari aspirasi karier juga masih berada pada kategori sedang. Komponen perilaku ini mencakup mempersiapkan perencanaan aktual, memilih strategi atau langkah-langkah yang akan dilakukan, dan berkerja keras dalam upaya mencapai tujuan yang telah ditentukan. Peserta didik masih berada pada kategori sedang dari tia indikator komponen perilaku ini, artinya peserta didik masih memerlukan pengembangan aspirasi karier kearah yang lebih realistis yakni dimana peserta didik sudah mampu membuat perncanaan dan strategi-strategi untuk mecapai karier yang diharapkan, serta pengaktualisasian perencanaan dan strategi dengan cara bekerja keras agar semua yang direncanakan dapat tercapai.

Peserta didik kelas $X$ berada pada tahapan orientasi diri (14 tahun keatas) dan pada asa ini peserta didk mengalami krisi identitas. Menurut Gottfredson pada tahap ini individu mulai memilih, menetapkan dan mencari alternatif mengenai perencanaan diri dan pekerjaannya. Peserta didik mempertimbangkan kepentingan mereka, kapasitas, dan nilai-nilai sebagai kriteria penting untuk mempersempit pilihan karier mereka. Dengan demikian, banyak pilihan karier telah dieliminasi melalui tahap-tahap perkembangan karena jenis kelamin, prestise, atau kesesuaian minat. Zona alternatif yang bisa diterima (aspirasi karier) menjadi lebih kecil dengan bertambahnya usia. 
Menurut Danziger dan Eden (2006:115), dijelaskan bahwa aspirasi karier adalah membina seseorang untuk mewujudkan tujuan karier yang diinginkan. Mereka juga berpendapat bahwa aspirasi karier yang terkait dengan harapan karier seseorang dan persepsi individu adalah gagasan dan penilaian, yang merupakan produk yang terdiri dari proses pengorganisasian mental, pengintegrasian, dan pengakuan terhadap kenyataan yang ada. Danziger dan Eden menjabarkan dari teori Gottfredson bahwa aspirasi karier idealis adalah tujuan karier yang diinginkan dan pengembangan aspirasi karier yang dilakukan merupakan proses mental. Perbedaan persepsi antara kedua jenis aspirasi ini oleh Danziger dan Eden disebut sebagai "kesenjangan harapan ".

Proses pemilihan karier untuk setiap individu adalah unik, karena antara individu satu dengan yang lain tidaklah sama, orientasi aspirasi seseorang dipengaruhi oleh berbagai faktor seperti jenis kelamin, status ekonomi, latar belakang keluarga, harapan orangtua, dan usia, serta kebijakan dan dukungan sekolah terhadap siswa juga dapat mempengaruhi aspirasi pemilihan karier seseorang.

Satatus sosial ekonomi merupakan salah satu faktor yang mempengaruhi perkembangan aspirasi karier individu. Pada penelitian ini, penentuan status sosial ekonomi peserta didik dilihat dari pendidikan terakhir orangtua dan penghasilan orang tua. Dalam pendidikan terakhir orangtua, peserta didik dikelompokkan menjadi 4 kelompok yakni pendidikan prasekolah, pendidikan dasar, pendidikan menengah dan pendidikan tinggi. Nilai rerata dari keempat kelompok tersebut cukup beraga namun masih berada dikategori yang sama yakni kategori sedang. Artinya pendidikan orang tua tidak terlalu memberikan perbedaan hasil rerata.

Sementara itu berdasarkan penghasilan orangtua, peserta didik dibagian kedalam lima kelompok berbeda. Dari kelima kelompok tersebut, kelompok peserta didik dengan jumlah penghasilan orangtua paling tinggi memiliki nilai rerata pada kategori tinggi pada indikator ide-ide alternatif komponen sikap dan indikator perencanaan yang aktual. Sementara untuk indikator lainnya dari masing-masing komponen dan pengelopokan berada pada kategori yang sama yakni kategori sedang dengan nilai rerata yang beragam.

Kategori sedang dapat menunjukkan bahwa peserta didik sudah bisa mengukur kemampuan finansial yang dimiliki orangtua. Terhalangnya harapan karier peserta didik oleh kemampuan finansial ini disebut sebagai hambatan karier. Hambatan karier ini muncul pada pembahasan konsep kelima Gottfredson yakni compromise. Gottfredson menyebutkan proses kompromi merupakan proses pencarian alternatif yang didasarkan pada realitas diluar diri individu. Hal ini berdasarkan bahwa lingkungan ikut andil mempengaruhi kesempatan seseorang memperoleh pekerjaan tertentu. Hakikat dari konsep 
kompromi dalam teori ini adalah proses dimana individu melepaskan pilihan yang telah ditetapkan kepada pilihan lain yang dianggap lebih realistis dan lebih mudah diraih. Kompromi bisa muncul ketika individu telah melakukan antisipasi terhadap kemungkinan eksternal, hal ini disebut dengan kompromi antisipatik, selain itu kompromi bisa muncul ketika hambatan sudah jelas terlihat, kompromi ini disebut degan experiental cmpromise. Untuk hambatan finansial ini masuk kedalam experiental compromise karena peserta didik sudah mengetahui bahwa terbatasnya penghasilan orangtua merupakan hambatan dalam pemilihan karier peserta didik, sehingga peserta didik harus mencari alternatif pilihan karier lain yang lebih sesuai dengan kondisi peserta didik.

Berdasarkan Women's Studies Encyclopedia, gender adalah suatu konsep kultural yang dipakai untuk membedakan peran, perilaku, mentalitas, dan karakteristik emosional antara laki-laki dan perempuan yang berkembang dalam masyarakat (Mulia, 2004: 4). Dalam penelitian ini, gender mengarah kepada peran sosial peserta didik di masyarakat.

Pada penelitian ini kecenderungan aspirasi karier peserta didik kelas X SMA Negeri 1 Batujajar berdasarkan gender memiliki nilai rerata yang beragam namun masih berada pada kategori yang sama yakni sedang. Artinya, pesert didik sedikit sudah mengerti dan mengetahui peran sosial mereka berdasarkan gender (laki-laki atau perempuan) bukan hanya dari cara berpakaian saja tetapi pada hal yang lebih kompleks lagi.

Perbandingan aspirasi karier peserta didik antara laki-laki dan perempuan menunjukkan signifikan sebesar 0,531, menunjukkan bahwa tidak terdapat perbedaan aspirasi karier antara laki-laki dan perempuan.

Dalam konsep aspirasi karier, gender seringkali disebut sebgai faktor yang mempengaruhi perkembangan aspirasi karier. Seperti yang disebutkan oleh Gottfredson menyatakan bahwa the acceptability of career alternatives to an individual is determined by three factors: occupation prestige, gender traditionality (or sex type) of occupations and occupational field, dapat dikatakan ada tiga faktor yang berpengaruh terhadap aspirasi karier dan pendidikan individu, yaitu: gengsi atau prestise, jenis kelamin dan minat pada lapangan pekerjaan tertentu. Gottfredson menegaskan bahwa ketiga faktor tersebut merupakan prinsip dalam proses yang dikenal "circumscription", di mana awalnya aspirasi individu dipengaruhi oleh jenis kelamin (umur 6-8 tahun), kemudian beralih berdasarkan gengsi atau prestise (umur 9-13 tahun) dan terakhir berdasarkan minat pada jenis pekerjaan tertentu (umur 14 tahun ke atas). 
Jika dilihat dalam konsep tersebut disebut jenis kelamin pada tahap kedua. Namun jenis kelamin disana hanya menunjukkan peran secara kasat mata, contohnya cara berpakaian dan belum kearah yang lebih kompleks lagi. Peran gender disebutkan dengan lebih kompleks pada tahap terakhir yakni orientasi diri, dimana pada tahapan ini peserta didik sudah bisa berpikir lebih konkret dan kompleks.

Tidak terdapatnya perbedaan yang signifinkan antara laki-laki dan perempuan dapat dipengaruhi oleh berbagai faktor. Ssaat ini sudah banyak kesetaraan dalam peran sosial untuk laki-laki dan perempuan. Contohnya pekerjaan sebagai koki atau juru masak, memasak yang biasanya lebih diidentikan dengan perempuan kini pekerjaan tersebut sudah banyak digeluti oleh laki-laki.

\section{SIMPULAN}

Secara umum, aspirasi karier peserta didik kelas $\mathrm{X}$ berada pada kategori sedang. Peserta didik kelas XI belum memiliki aspirasi karier sesuai dengan tahap perkembangan kariernya. Hal ini dapat dianggap wajar dengan mempertimbangkan perkembangan remaja secara psikis dan tahap perkembangan kariernya. Untuk mempersiapkan peserta didik yang mampu mengambil keputusan dalam pemilihan karier nya maka aspirasi peserta didik harus llebih ditingkatkan pada kategori tinggi dan sangat tinggi atau dalam hal ini harus meningkatkan aspirasi karier peserta didik agar lebih realistis.

Berdasarkan status sosial ekonomi dilihat dari tingkat pendidikan terakhir orang tua dan penghasilan otangtua. Dari pengelompokan pendidikan terakhir orangtua tidak terdapat perbedaan kategori dari masing-masing kelompok, semua kelompok berada pada kategori sedang, artinya tingkat pendidikan orang tua tidak menjadi hambatan dalam pemilihan karier peserta didik. Namun itu bisa menjadi motivasi supaya mendapatkan pendidikan yang lebih baik dibandingkan orangtua. Sementara itu hasil dari pengelompokan berdasarkan penghasilan orang tua memiliki beberapa perbedaan kategori. Pada dua indikator kelompok dengan penghasilan orangtua paling tinggi berada pada kategori tinggi sementara yang lainnya berada pada kategori rendah.berdasarkan kedua komponen tersebut, status sosial ekonomi bisa menjadi hambatan maupun motivator bagi peserta didik.

Stereotipe gender dalam aspirasi karier tidak memiliki perbedaan yang signifian dan cenderung sama, hal ini dilihat dari nilai signifikansi dan rerata dari laki-laki dan perempuan tidak terlalu berbeda meskipun beragam tetapi masih berada pada kattegori yang sama yakni sedang.

Karier merupakan bagian dari proses kehidupan peserta didik, dan pengambilan keputusan diperlukan dalam pencapaian karier. salah satu faktor 
yang mempengaruhi pengambilan keputusan karier adalah aspirasi karier. Aspirasi karier merupakan refleksi dari self-concept karier. Asprasi karier berkembang semenjak post-natal hingga dewasa dan menjadi semakin stabil ketika menginjak dewasa. Aspirasi karier peserta didik perlu dirahakan agar peserta didik mempu menilai kemampuan, minat dan nilai-nilai yang berlaku.

Peran bimbingan dan konseling juga sangat penting untuk memberikan informasi terkait dengan berbagai pilihan karier yang ada sehingga siswa memiliki banyak referensi dalam proses pengambilan keputusan kariernya. Untuk dapat memfasilitasi peserta didik dengan tepat, Guru BK perlu memperkaya diri dengan pengetahuan dan keterampilan terkait dengan karier, baik mengenai fenomena, solusi untuk mengatasi berbagai hambatan karier, dan upaya menyiapkan peserta didik yang siap mencapai karier yang diimpikannya. Dengan demikian, diperlukannya keaktifan Guru BK untuk melakukan pengembangan diri melalui seminar, pelatihan, atau membaca referensi yang berkaitan dengan karier, lebih khususnya lagi mengenai aspirasi karier.

\section{REFERENSI}

Anderson, P., \& Vandehey, M. (2012). Career Counseling and Development in Global Economy. USA: Brook/Cole Cengage Learning.

Bakar, A. R., \& Mohamed, S. (2004). Academic performance, educational and occupational aspirations of technical secondary school students. Pertanika Journal of Social Science and Humanities, 12(1), 31-43.

Brown, S. D., \& Lent, R.W. (2005). Career development and counseling: Putting theory and research to work: Applying Gottfredson theory of circumsdription and compromise in career guidance and counseling (hal $71-100$ ). New York: Wiley.

Creed, P. A., Wong, O. Y., \& Hood, M. (2009). Career decision-making, career barriers and occupational aspirations in Chinese adolescents. International Journal for Educational and Vocational Guidance, 9(3), 189-203.

Creswell, J. W. (2012). Educational research (4th Edition). Boston: Pearson.

Departemen Pendidikan Nasional. (2008). Penataan Pendidikan Profesional Konselor dan Layanan Bimbingan dan Konseling dalam Jalur Pendidikan Formal. Jakarta: Depdikbud.

Faridah, N. (2014). Hubungan Antara Aspirasi Karir Dengan Kematangan Vokasional Pada Siswa SMK Walisongo 1 Gempol Pasuruan (Tesis, UIN Sunan Ampel Surabaya). 
Gottfredson, L. S. (1981). Circumscription and compromise: A developmental theory of occupational aspirations. Journal of Counseling Psychology, 28(6), 545-579.

Gunarsah, S. (2003). Perkembangan Anak dan Remaja. Jakarta: Gunung Mulia.

Mulia, S, M. (2004). Islam Menggugat Poligami. Jakarta: Gramedia Pustaka Utama.

Peraturan Pemerintah Nomor 27 Tahun 1990 tentang Pendidikan Prasekolah.

Peraturan Pemerintah Nomor 28 Tahun 1990 tentang Pendidikan Dasar.

Peraturan Pemerintah Nomor 29 Tahun 1990 tentang Pendidikan Menengah.

Rojewski, J. W., \& Yang, B. (1997). Longitudinal analysis of select influences on adolescents' occupational aspirations. Journal of Vocational Behavior, 51(3), 375-410.

Rahayu, S. E. (1999), Perbedaan Aspirasi karir antara remaja laki-laki dan perempuan yang mempunyai intelegensi tinggi (Skripsi, Universitas Katolik Soegijapranata, Semarang).

Santrock, J. W. (2002). Life Span Developmental: Perkembangan Masa Hidup (Edisi Kelima). Alih Bahasa: Achmad Chusairi, Juda Damanik; Editor: Herman Sinaga, Yati Sumiharti. Jakarta: Erlangga.

Santrock, J. W. (2003). Perkembangan Remaja (Edisi keenam). Jakarta: Erlangga.

Santrock, J. W. (2007). Psikologi pendidikan (Edisi Kedua). Alih Bahasa: Tri Wibowo. Jakarta: Erlangga.

Setyowati, R., \& Riyono, B. (2003). Perbedaan Aspirasi Karir Antara Wanita yang Sudah Menikah dan yang Belum Menikah Pegawai Negeri Sipil. Psikologika: Jurnal Pemikiran dan Penelitian Psikologi, 8(16), 52.

Sifah, E. Z. (2015). Pengaruh Efikasi Diri Terhadap Aspirasi Karir Pada Siswa Kelas X SMA Negeri 1 Depok Sleman Yogyakarta. Skripsi Universitas Negeri Yogyakarta, Yogyakarta.

Sudjana, N. \& Ibrahim. (2007). Penelitian dan Penilaian Pendidikan.Bandung: Sinar Baru Algensindo.

Undang-Undang Republik Indonesia Nomor 12 Tahun 2012 tentang Pendidikan Tinggi.

Undang-Undang Republik Indonesia Nomor 20 Tahun 2003 tentang Sistem Pendidikan Nasional.

Winkel, W. S., \& Hastuti, M. S. (2005). Bimbingan dan konseling di institusi pendidikan. Jakarta: Gramedia Widiasarana Indonesia. 